\title{
Gastropods in subterranean shelters of the Czech Republic
}

\author{
LIBOR DVOŘÁK
}

Šumava National Park Administration, Dept. of Science and Research, Sušická 399, CZ-34192 Kašperské Hory, Czech Republic, e-mail: libor.dvorak@npsumava.cz

\begin{abstract}
DVOřÁK L., 2005: Gastropods in subterranean shelters of the Czech Republic. - Malacologica Bohemoslovaca, 4: 10-16. Online serial at $<$ http://mollusca.sav.sk $>$ 15-Sep-2005.

Gastropods in different types of cellars, nature caves, abandoned galleries, and military bunkers have been studied. The major part of localities is situated in W and SW Bohemia, findings from other parts of the Czech Republic are scarce. Species at different types of subterranean shelters are listed. Some interesting features, e.g., remarkable species, big specimens, depigmented populations, and hibernating snails, are mentioned.
\end{abstract}

\section{Introduction}

Although molluscs are well-studied group of animals, no complex studies from subterranean shelters (excluding troglobionts) were published. Several data are available on occurrence of typical species (e.g., Limacus flavus, Limax maximus, Oxychilus cellarius, $O$. draparnaudi, etc.) in cellars, predominantly in papers on mollusc faunas in towns (KLAUSNITZER 1988, SEIDL 1955, JUŘIČKOVÁ 1995, STRZELCZYK 1995).

Preliminary results of the author's survey were published (DVOŘÁK 1999), as well as summary of records from limestone caves of SW Bohemia (DVOŘÁK 2003). This study uses data, which were published in both papers (DVOŘÁK 1999, 2003) and adds new unpublished data.

\section{Material and Methods}

Gastropods were found within the entire space of the shelter - on walls, ceilings, and grounds, under bricks, wood blocks, or in debris. The author did this research with a hand lamp and under a direct picking; sifting was not used. The research was done mostly in a winter time due to a possible immigration of gastropods from a cold outer neighbourhood. Collected specimens were determined according to LOŽEK (1956) and KERNEY et al. (1983). Specimens of Deroceras reticulatum, Limacus flavus, as well as some specimens of Limax sp., Arion sp., Aegopinella sp., Oxychilus sp., and Lehmannia marginata were dissected. The major part of collected specimens is deposited in the author's collection.

\section{List of localities}

All localities are listed in the following order: number of a grid system of the Czech Republic (PRUNER \& MíkA 1996), locality (listed alphabetically), stand, and date(s) of findings. See information map of localities on Fig. 1.

1 5644, Korunní, gallery, 12 Feb 2000. 2 5739, Podhradí, cellars of former castle Neuschloss, 4 Feb 1997, 6 Feb 1998, 11 Feb 2001. 3 5739, Podhradí, cellars of former castle Spodní zámek, 3 Feb 2004. 4 5740, Horní Luby, cellars of castle, 12 Feb 2001, 24 Feb 2003, 3 Feb 2004. 5 5743, Karlovy Vary, cellars of hotel Sevastopol, 12 Feb 2000. 6 5839, Hazlov, gallery by creek, 4 Feb 2003. 7 5839, Libá, cellars of castle, 11 Feb 2001. 8 5839, Pomezná, cellars of former fortress, 11 Feb 2001, 4 Feb 2003. 9 5840, Skalná, cellars of castle, 14 Feb 1996, 4 Feb 1997, 6 Feb 1998, 15 Feb 1999. 10 5840, Skalná, small cellar near house No. 198, 4 Feb 1997, 6 Feb 1998, 15 Feb 1999. 11 5840, Starý Rybník, cellars of castle, 14 Feb 1996, 4 Feb 1997, 3 Feb 2004. 12 5841, Kostelní Bříza, cellars under castle park, 13 Feb 1996, 10 Feb 2001, 31 Jan 2003. 13 5842, Horní Slavkov, cellars behind former petrol pump, 13 Feb 1996, 2 Feb 1997, 6 Feb 1998, 10 Feb 2001, 31 Jan 2003. 14 5842, Loket, cellars by bridge near porcelain factory Thun, 1 Feb 2004. 15 5842, Loket, cellars by railway station, 4 Feb 1997. 16 5842, Staré Sedlo, cave Kančí, 25 Feb 2003. 


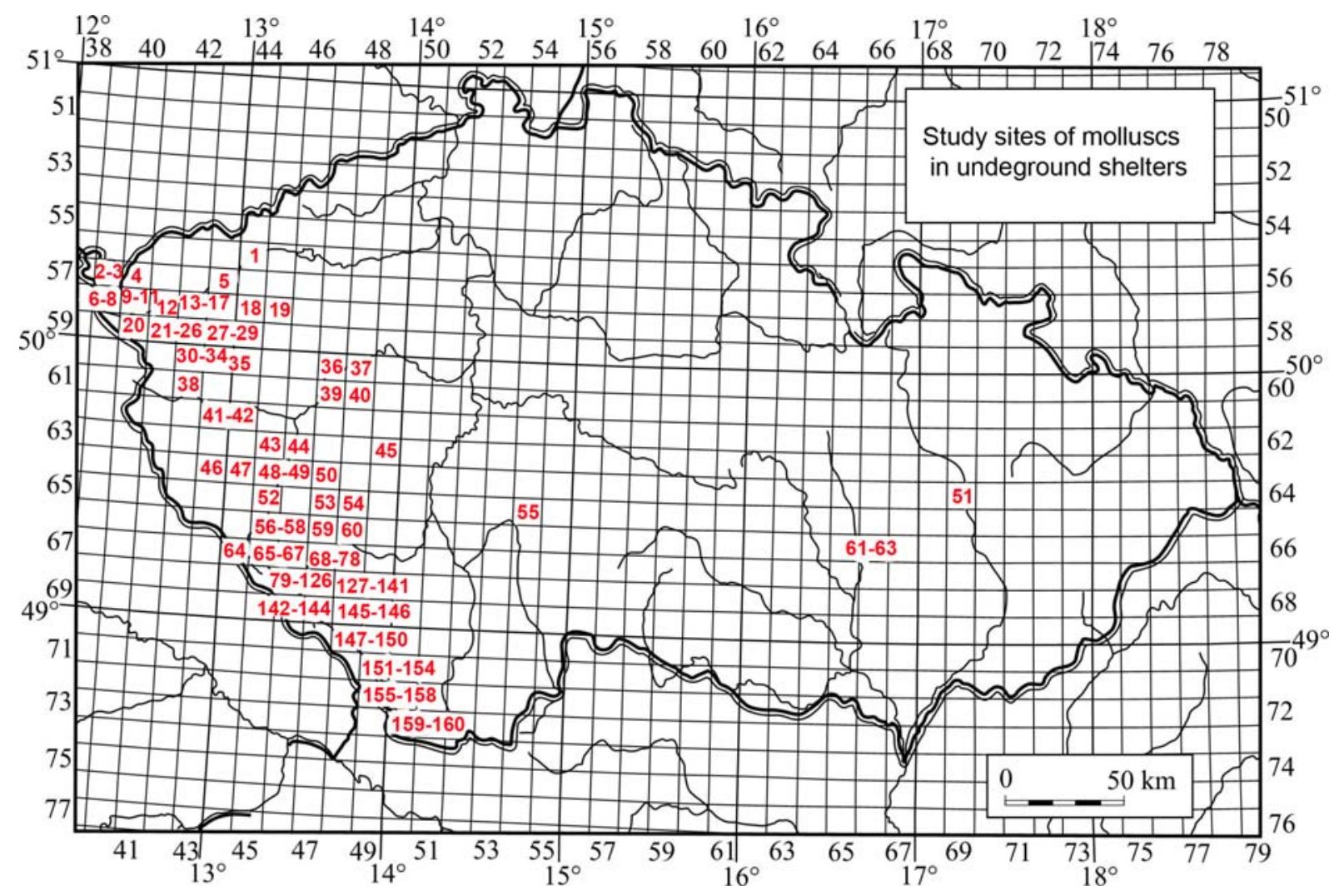

Fig. 1. A schematic map of surveyed localities.

17 5842, Údolí, cellar of house, 1 Feb 2004. 18 5844, Luka, brewery cellars, 14 Feb 1999, 12 Feb 2000. 19 5845, Zlatý vrch, gallery, 12 Feb 2000, 12 Feb 2001. 20 5940, Kyselecký Hamr, cellar, 1 Feb 2003. 21 5941, Krásná Lípa, cellars of former castle, 10 Feb 2001, 31 Jan 2003. 22 5941, Zámek Kynžvart, cellars of brewery, 12 Feb 1996. 23 5941, Zámek Kynžvart, cellars in the rock, 5 Feb 1997. 24 5942, Bečov nad Teplou, small cellar near turning to Louka, 9 Feb 2001, 1 Feb 2003, 29 Jan 2004. 25 5942, Bečov nad Teplou, gallery, 7 finds from Jan-Feb 1996-2004. 26 5942, Prameny, gallery Levá Amálka, 5 Feb 1998. 27 5943, Bečov nad Teplou, cellars of castle, 9 Feb 2001, 31 Jan 2003. 28 5943, Bečov nad Teplou, gallery under railway line, 13 Feb 1996. 29 5943, Toužim, cellars of castle, 12 Feb 1999. 30 6042, Boněnov, gallery Portál, 2 Feb 2003. 31 6042, Michalovy Hory, gallery Barbora, 6 finds from Jan-Feb 1996, 19992004. 32 6042, Pístov, small cellar, 4 Feb 1998, 13 Feb 2000, 9 Feb 2001. 33 6042, Výškovice, gallery Cave of Incas, 2 Feb 1997, 13 Feb 2000. 34 6042, Výškovice, gallery S jezírkem, 2 Feb 1997, 13 Feb 1999, 13 Feb 2000. 35 6043, Klášter Teplá, cellars of monastery, 9 Feb 2001. 36 6047, Liblín, cellars of distillery, 6 finds from Jan-Feb 1996, 1997, 20002004. 37 6048, Modřejovice, small cellar by road, 10 Feb 2000, 6 Feb 2001. 38 6142, Planá u Mariánských Lázní, cellars of house No. 770, 19 Apr 2003. 39 6147, Svinná, cellars of castle, 10 Feb 2000, 6 Feb 2001, 28 Jan 2003, 28 Jan 2004. 40 6148, Plískov, gallery on hill Bukov, 28 Jan 2003. 41 6243, Stříbro, gallery Urban II, 26 Jan 2004. 42 6243, Stříbro, gallery Urban IV, 27 Jan 2003. 43 6345, Chotěšov, cellars of monastery, 5 finds from Jan-Feb 1996-2003. 44 6346, Dolní Lukavice, cellars of gardening., 7 Feb 1996, 8 Feb 2000, 30 Jan 2001, 20 Feb 200345 6349, Lázský rybník reservoir, upper tunnel in dike, 27 Feb 2001. 46 6443, Horšovský Týn, cellars of castle, 13 Feb 1997, 7 Feb 2000. 47 6444, Holýšov, gallery, 6 Feb 1996, 13 Feb 1997, 7 Feb 2000, 29 Jan 2003. 48 6445, Červené Poŕíćí, cellars of brewery, 8 Feb 2000. 49 6445, Roupov, cellars of castle, 14 Feb 1997. 50 6447, Blovice, cellars of manor, 8 Feb 2000, 20 Feb 2003. 51 6469, Olomouc, cellars of house in Heydukova street, 14 Nov 2003. 52 6545, Chudenice, gallery Na Vápence, 25 Oct 2000. 53 6547, Nepomuk, cellars of brewery, 14 Feb 1997. 54 6548, Zlatá hora, gallery, 7 Jan 1997. 556554 Chýnov, Chýnovská cave, 16 May 2000. 56 6645, Loreta, gallery, 9 finds from Jun, Apr, Jul, Dec 1998-2002. 57 6645, Týnec, cellars of castle, 7 Feb 1996. 58 6646, Mlázovy, cellars of castle, 6 finds from Jan, Mar, Nov, Dec 1995, 1996, 1998, 2000. 59 6647, Nalžovské Hory, cellars of castle, 11 Jul 1996. 60 6648, Prácheň, gallery, 27 Nov 1996, 21 Mar 1997, 21 Jul 1999, 13 Oct 2000. 61 6666, Moravian Karst, Hadí cave, 10 Mar 2001. 62 6666, Moravian Karst, cave in valley Vaječník, 29 Jul 2001. 63 6666, Moravian Karst, Jurová cave, 19 Dec 2001. 64 6744, Svatá Kateřina, gallery, 7 finds from Nov-Jan 1998-2003. 65 6745, Březí, cellars by pond, 27 Nov 2000. 666745 , 
Čachrov, cellars of fortress, 9 Jan 1996. 67 6746, Hrádek u Sušice, cellars of castle, 5 finds from Jan and Nov 1996, 1997, 2000, 2001. 68 6747, Budětice, cellars of house No. 10, 9 finds from almost all months 1996, 1999-2002. 69 6747, Čepice, gallery, 33 finds from almost all months 1996, 1999-2004. 706747 , Dobršín, cave Na Svatu, 23 Apr 2000, 22 May 2001, 27 Feb 2002, 16 Oct 2002. 71 6747, Chanovec, gallery, 15 finds from different months 1996-2003. 72 6747, Rabí, cellars of castle, 3 Dec 2003. 73 6747, Sušice, Lysandrovské sklepy cellars (No. 310), 29 Nov 2000, 27 Feb 2002. 74 6747, Sušice, gallery U čističky, 7 finds from Nov-Jan 1997-2002. 75 6747, Sušice - pod Svatoborem, cellar of summerhouse of J. Havránek, 19 Jul 199976 6747, Sušice - pod Svatoborem, cellar of summerhouse of R. Sloup, 13+20 Jul 1999. 77 6747, Žichovice, cave, 26 Oct 2000. 78 6747, Žichovice, small gallery, 4 finds from Nov-Jan 2000 2003. 79 6846, Dobrá Voda, cellars of school, 25 Oct 1996. 80 6846, Peklo, cave, 21 Oct 1998, 22 Nov 1999, 18 Oct 2001. 81 6846, Peklo, cave Peklo I, 13 Jan 2000, 15 Nov 2002. 82 6846, Prášily, brewery cellars, 9 Oct 1996. 83 6847, Amálino údolí, gallery A, 20 finds from almost all months 1996-2003. 84 6847, Amálino údolí, gallery B, 10 finds from Aug-Mar 1999-2002. 85 6847, Amálino údolí, gallery Bedřich, 6 finds from Mar, Oct, Nov 2000-2003. 86 6847, Amálino údolí, gallery I, 15 Nov 1999, 14 Dec 1999. 87 6847, Amálino údolí, gallery II, 19 finds from almost all months 1995-2003. 88 6847, Amálino údolí, gallery Myší díra, 22 Sep 1995, 15 Sep 2000. 89 6847, Amálino údolí, gallery Nad Nadějí, 20 Nov 1996, 27 Nov 1997, 22 Dec 1999. 90 6847, Amálino údolí, gallery Průchodná, 9 finds from Jan, Mar, SepNov 1998-2002. 91 6847, Amálino údolí, gallery Překvapení, 27 Oct 2000, 3 Oct 2001, 9 Nov 2001. 92 6847, Amálino údolí, gallery Sněmovní, 15 Oct 1998, 16 Sep 1999, 15 Sep 2000. 93 6847, Amálino údolí, gallery Štolička, 15 Sep 2000, 9 Nov 2001. 94 6847, Amálino údolí, gallery Veřejné záchodky, 15 Sep 2000, 3 Oct 2001, 13 Mar 2002, 30 Aug 2002. 95 6847, Amálino údolí, gallery Vlevo, 16 Sep 1999, 23 Nov 2000. 96 6847, Amálino údolí, gallery Vpravo, 19 Jan 2001. 97 6847, Amálino údolí, gallery Za křižovatkou, 5 finds from Sep-Dec 1999-2001. 98 6847, Bohdašice, bunker 31, 1 Oct 1998. 99 6847, Buzošná, cellars of destroyed mill, 31 Oct 1996, 11 Sep 1997, 13 Nov 1997. 100 6847, Kašperské Hory, cellars of house No. 184, 6 finds from Jan, Jul, Sep, Nov, Dec 1995-1997. 101 6847, Nezdice, cave Fík, 3 Feb 2002, 12 Nov 2002, 3 Jan 2004, 4 Jan 2005. 102 6847, Nové Městečko, bunker 34, 1 Oct 1998. 103 6847, Opolenec, bunker 15, 12 Sep 2000, 16 Aug 2002, 1 Sep 2004. 104 6847, Opolenec, bunker 17, 12 Sep 2000. 105 6847, Opolenec, bunker 27, 10 Sep 1999, 12 Sep 2000. 106 6847, Opolenec, bunker 28, 10 Sep 1999, 12 Sep 2000. 107 6847, Podzuklín, cellars of gamekeeper's lodge, 23 Nov 1999, 30 Dec 1999. 108 6847, Podzuklín, cellars in rock, 18 Oct 2001. 1096847 , Ramajzl, bunker 37, 2 Oct 1998, 13 Oct 1999, 15 Nov
2000. 110 6847, Ramajzl, bunker 39, 2 Oct 1998, 15 Nov 2000, 10 Oct 2001. 111 6847, Ramajzl, bunker 40, 2 Oct 1998, 13 Oct 1999, 15 Nov 2000. 112 6847, Ramajzl, bunker 8, 25 Sep 1998, 13 Oct 1999, 15 Nov 2000. 113 6847, Strašín, cave, 10 finds from Mar, Sep-Jan 1995-2003. 114 6847, Tuškov, bunker 11, 10 Sep 1998, 12 Sep 2000, 16 Aug 2002. 115 6847, Tuškov, bunker 12, 10 Sep 1999, 9 Dec 1999, 12 Sep 2000, 1 Sep 2004. 116 6847, Tuškov, bunker 13, 10 Sep 1999, 12 Sep 2000. 117 6847, Tuškov, bunker 14, 16 Aug 2002. 118 6847, Tuškov, bunker 29, 12 Sep 2000, 16 Aug 2002. 119 6847, Ždánov, bunker 22, 7 May 1998, 13 Oct 1999. 120 6847, Ždánov, bunker 23, 7 May 1998, 13 Oct 1999, 22 Mar 2001. 121 6847, Ždánov, bunker 4, 20 Jan 1997, 13 Oct 1999, 15 Nov 2000. 122 6847, Ždánov, bunker 5, 4 Nov 1996, 15 Nov 2000, 30 Jan 2002. 123 6847, Ždánov, small cellar by road, 15 Nov 2000. 124 6847, Ždánov, galleries, 13 Oct 1998, 6 Dec 2001. 125 6847, Žlíbek, bunker 51, 30 Jan 2002. 126 6847, Žlíbek, bunker 6, 5 finds from Jan, Mar, Sep-Nov 1998-2002. 127 6848, Čestice, cellars under castle park, 9 Nov 2000, 16 Dec 2000. 128 6848, Čkyně, cellars by castle, 16 finds from Sep-Mar 1996-2005. 129 6848, Jaroškov, cellar of house No. 5, 6 Nov 1994, 20 Jul 1995. 130 6848, Maleč, cellars of house No. 6, 29 Sep 1999. 131 6848, Maleč, cellars of school, 9 finds from almost all months 1995-2001. 132 6848, Mladíkov, cave, 28 Jan 2001, 17 Aug 2001. 133 6848, Přečín, cellars of castle, 13 finds from Jun, Sep-Mar 1996-2002. 134 6848, Vacov, cellars of house No. 74, 29 Oct 2001. 135 6848, Vacov, cellars of rectory, 30 Nov 1996. 136 6848 , Vacov, small cellar by the house No. 9, 28 Sep 2001. 137 6848, Vacov, water supply shaft by panel house, 15 Jul 1996. 138 6848, Vacov, water supply shaft by post office, 23 Sep 1995. 139 6849, Lčovice, cellars near castle, 6 finds from Jun, Oct, Dec-Mar 1996-1998. 140 6849, Malenice, cave Jiřičkova sluj, 11 Oct 2001, 8 Mar 2002. 141 6849, Malenice, cave Na Betani, 23 Nov 1999, 3 Nov 2000, 11 Oct 2001. 142 6946, Na Vrchách, bunker 3, 25 Oct 1996. 143 6947, Zhưríi, bunker 1, 30 Oct 2000, 13 Sep 2002. 144 6947, Zhůř́i, bunker 2, 18 Oct 1996, 30 Oct 2000, 13 Sep 2002. 145 6948, Sudslavice, cave, 5 finds from Jan, May, Aug, Sep 1997-2002. 146 6948, Vimperk, cellars of castle, 6 Mar 1996, 20 Dec 1999. 147 7048, Zátoň, bunker 10, 26 Jun 1996. 148 7048, Zátoň, bunker 9, 26 Jun 1996, 2 Oct 1997, 11 Jul 1998, 15 Nov 1998. 149 7049, Krejčovice, gallery, 16 Dec 1999, 6 Jan 2005. 150 7049, Mlynářovice, gallery, 16 Dec 1999, 10 Nov 2000. 151 7149, Chlum, cellars of former school, 22 Jan 2001. 152 7149, Pěkná, bunker 50, 22 Sep 1999. 153 7150, Michal, bunkers 18+19, 30 Sep 1997. 154 7150, Žumberská dolina, cellar of ruin, 10 Nov 2000, 11 Dec 2000. 155 7249, Hut'ský Dvůr, gallery in quarry, 29 Jun 1996. 156 7249, Zadní Zvonková, bunker 20, 1 Oct 1997. 157 7250, Mokrá, cellar of manor, 14 Mar 2000. 158 7250, Muckov, gallery, 30 Jun 1999, 21 Sep 1999, 16 Dec 1999, 2 Nov 2003. 159 7350, Svatý Tomáš, cellars of castle, 1 Jul 1999, 
16 Dec 1999, 26 Jun 2000. 160 7351, Frymburk, Faitl's cellar, 14 Mar 2000.

\section{List of species}

Nomenclature follows JUŘIČKOVÁ et al. (2001), numbers under every species correspond with the list of localities.

Lymnaeidae

Radix peregra s.str. (O.F. Müller, 1774): 26

Cochlicopidae

Cochlicopa lubrica (O.F. Müller, 1774): 105, 110, $112,116,143,144,152,154$

Valloniidae

Acanthinula aculeata (O.F. Müller, 1774): 110

Vertiginidae

Vertigo pusilla O.F. Müller, 1774: 110

Clausiliidae

Cochlodina laminata (Montagu, 1803): 70, 145

Macrogastra plicatula (Draparnaud, 1801): 62, 81, 110,112

Macrogastra ventricosa (Draparnaud, 1801): 109, 110, 112

Clausilia cruciata (Studer, 1820): 110

Alinda biplicata (Montagu, 1803): 43, 70, 101, 110

Bulgarica cana (Held, 1836): 110

Punctidae

Punctum pygmaeum (Draparnaud, 1801): 105

Discidae

Discus rotundatus (O.F. Müller, 1774): 4, 9, 36, 44, 52, 55, 58, 67, 71, 81, 85, 105, 107, 109, 110, 112, $113,128,131,132,133,136,139,142,150,158,160$ Discus ruderatus (A. Férussac, 1821): 19, 154

Euconulidae

Euconulus fulvus (O.F. Müller, 1774): 105, 109, 110, 143,144

Vitrinidae

Vitrina pellucida (O.F. Müller, 1774): 19, 106, 114, $115,116,122,144,154$

Eucobresia diaphana (Draparnaud, 1805): 71, 81, 112, 121

Semilimax semilimax (J. Férussac, 1802): 83, 85, 105, $106,108,110,115,123,141,143$

Zonitidae

Aegopis verticillus (Lamarck, 1822): 63

Aegopinella minor (Stabile, 1864): 71, 141

Aegopinella nitens (Michaud, 1831): 39, 85, 109, 110, $112,154,159$

Aegopinella pura (Alder, 1830): 152

Perpolita hammonis (Ström, 1765): 19, 105, 116, 143, 143

Oxychilus cellarius (O.F. Müller, 1774): 2, 8, 11, 21, $32,34,39,46,48,55,58,61,67,68,69,73,81,100$,

$107,112,113,128,129,131,133,134,136,140,141$, $145,146,149,155,156,158,159,160$

Oxychilus depressus (Sterki, 1880): 60, 84, 85, 150

Oxychilus draparnaudi (Beck, 1837): 4, 9, 36, 43, 44, 48, 67, 139, 160

Oxychilus glaber (Rossmässler, 1835): 62, 63, 140, 141,145

Limacidae

Limax cinereoniger Wolf, 1803: 1, 2, 7, 12, 13, 14, 15, $23,25,31,33,36,40,47,54,55,56,64,69,71,74$, $80,82,83,84,85,87,88,90,91,92,94,95,97,101$, $103,104,105,106,108,109,110,111,112,113,114$, $115,117,118,120,126,128,135,141,142,144,148$, 156,159

Limax maximus Linnaeus, 1758: 2, 4, 6, 7, 9, 10, 11, $12,13,18,25,26,27,35,36,38,39,41,43,44,47$, $56,57,58,66,67,68,69,73,75,76,77,78,79,82$, $128,133,136,138$

Limacus flavus (Linnaeus, 1758): 51

Malacolimax tenellus (O.F. Müller, 1774): 64, 84, 85, 91, 97, 103, 112, 126

Lehmannia marginata (O.F. Müller, 1774): 9, 19, 20, $31,32,33,42,60,69,71,82,83,84,85,87,89,90$, $91,92,93,97,99,109,120,122,159$

Agriolimacidae

Deroceras reticulatum (O.F. Müller, 1774): 76, 139, 141,152

Boettgerillidae

Boettgerilla pallens Simroth, 1912: 45, 73, 133

Arionidae

Arion distinctus Mabille, 1868: 68, 84, 85, 128, 133

Arion fasciatus (Nilsson, 1823): 36, 65, 76, 133

Arion lusitanicus Mabille, 1868: 3, 47, 101

Arion rufus (Linnaeus, 1758): 36, 58

Arion silvaticus Lohmander, 1937: 81

Arion subfuscus (Draparnaud, 1805): 69, 70, 71, 83, $87,92,93,96,97,103,106,110,114,120,124,126$, $131,133,139,140,159$

Bradybaenidae

Fruticicola fruticum (O.F. Müller, 1774): 5, 60, 77, 140

Hygromiidae

Euomphalia strigella (Draparnaud, 1801): 37

Petasina unidentata (Draparnaud, 1805): 81, 110, 111, 158

Trichia hispida (Linnaeus, 1758): 39, 44, 58, 81, 98, $109,110,130,131,133,136,139,147,152,154,159$, 160

Trichia sericea (Draparnaud, 1801): 9

Monachoides incarnatus (O.F. Müller, 1774): 8, 19, $44,70,71,81,84,85,101,107,109,110,111,112$, $115,116,126,131,141,148,153,154,155,158,159$ Urticicola umbrosus (C. Pfeiffer, 1828): 107, 109, 110, 111, 112, 154

Helicidae 
Arianta arbustorum (Linnaeus, 1758): 2, 4, 8, 10, 16, $17,21,43,58,80,97,99,106,107,119,121,123$, $135,139,143,148,154,156,157,159,160$

Helicigona lapicida (Linnaeus, 1758): 15, 24, 25, 27, $30,52,60,69,70,71,74,78,81,83,84,86,87,89$, $90,94,99,101,113,114,122,125,132,158$

Isognomostoma isognomostomos (Schröter, 1784): 70, $71,109,110,111,112$

Causa holosericea (Studer, 1820): 109, 110, 111, 112, 142,149

Cepaea hortensis (O.F. Müller, 1774): 2, 13, 17, 36, $37,39,43,44,48,58,98,102,115,118,127,133$, $136,137,159$

Cepaea nemoralis (Linnaeus, 1758): 9

Helix pomatia Linnaeus, 1758: 2, 5, 8, 9, 11, 13, 18, $22,28,29,36,37,39,43,44,48,49,50,53,58,59$, $69,71,72,74,112,113,116,121,125,127,131,133$, $139,140,141,145,151,153$

\section{Results and discussion}

Gastropods were found at 160 localities: 29 military bunkers, 15 karst or pseudokarst caves, 73 cellars of different types, and 43 galleries (old gold, silver, graphite, limestone, and other subterranean mines). A total number of 53 species of Gastropods were found. There were 948 positive controls (with presence of some species at any locality). Some localities were visited repeatedly.

The most constant species throughout the whole spectrum of shelters was Limax cinereoniger (59 localities) followed by Limax maximus (39), Helix pomatia (39), Oxychilus cellarius (37), Helicigona lapicida (28), Discus rotundatus (27), Arianta arbustorum (26), Lehmannia marginata (26), and Monachoides incarnatus (25).

The lowest number of species was found in natural caves: 24 species. However, the low number may result from a low number of surveyed caves (15). Most often recorded species were Oxychilus cellarius (7 localities), Limax cinereoniger, Oxychilus glaber, and Helicigona lapicida (5 localities). Findings in caves reflect assemblages of their surroundings; e.g. Petasina unidentata, Aegopis verticillus, and Arion silvaticus were found in caves surrounded by a mixed forest cover, while Fruticicola fruticum and Aegopinella minor were found in warm limestone areas. Findings of petrophilous and/or epilithic species as Helicigona lapicida, and Isognomostoma isognomostomos are typical. The most typical cave species is Oxychilus glaber. This troglophilous species (RIEDEL 1996) was found in 5 limestone caves ( 2 in Moravian Karst, 3 in SW Bohemia) only. The findings in SW Bohemia are remarkable because $O$. glaber occurs in this region only in a small area including all three caves (DVOŘÁK 2003).

Different subterranean shelters indicate galleries. This type of shelter comprises all man-made rock cavities primarily originated as mines, and which was not used after the end of mining. The number of species found at these stands is 26 . The most frequent species in galleries were Limax cinereoniger (23 localities), Lehmannia marginata (17), Helicigona lapicida (16), and Arion subfuscus (9). All mentioned species prefer this type of shelter. The major part of galleries is situated in forests, and the high representation of forest species is an expected result (18 species from 26). The occurrence of two species is remarkable. Radix peregra s.str. was found ca. $2 \mathrm{~m}$ deep in one water-flooded gallery. Troglophilous (RIEDEL 1996) and scarcely occurred species Oxychilus depressus were found in four galleries only, but not in the other types of shelters.

There were found 31 species in 73 cellars. In this type of shelters are comprised big cellars of significant buildings (castles, monasteries), as well as little cellars in houses, used cellars in rock and other man-made and man-used subterranean spaces (except military bunkers). The highest representation contains following species: Limax maximus (30 localities), Helix pomatia (26), Oxychilus cellarius (23), Arianta arbustorum (17), and Cepaea hortensis (15). All mentioned species occur in cellars with a higher frequency than in galleries, for example. Other species typical for cellars are Trichia hispida (17 localities, 11 are cellars), Oxychilus draparnaudi (its all 9 localities are cellars), Arion fasciatus (4), and Boettgerilla pallens (3). The majority of species occurring in cellars (ca. 50\%) forms euryoecious species. Very interesting species is Limacus flavus (Fig. 2). Only two localities of this species are known in the past two decades from the Czech Republic: Prague - Košíře, Zapova street, 1991, LOŽEK in JUŘIČKOVÁ (1995), and locality No. 51 of this study. L. flavus was firstly recorded at this locality on the $3^{\text {rd }}$ of Sep 2003 (M. Maňas and M. Kutal, 2 ex.), than on the $14^{\text {th }}$ of Nov 2003 (L. Dvoŕák and M. Maňas, 2 ex.). Data from East Germany show (BAADE 2003), that this species is not as rare as thought and can be found at suitable stands in some regions.

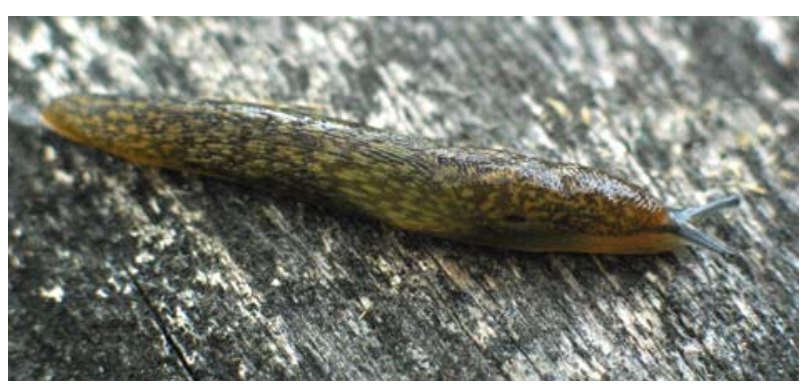

Fig. 2. Limacus flavus from locality No. 51 (Olomouc). Photo: M. Rudlová

Military bunkers are situated predominantly in the Bohemian forest and its foothills. The majority of the 33 recorded species represent forest species. No typical ruderal species were listed between 10 euryoecious species at these stands. These results reflect gastropods fauna in bunkers surroundings. The most common 
species in bunkers were Limax cinereoniger (18 localities), Monachoides incarnatus (9), and Cochlicopa lubrica (7). Some significant and rare species were found in bunkers inside of a broad leaf forest, e.g. Bulgarica cana, Clausilia cruciata or Causa holosericea.

Subterranean shelters do not represent enemy milieu for gastropods and many of species can be found in mass numbers here. The highest numbers were found in cellars - Arianta arbustorum (209, 124, 64 or 63 individuals), Oxychilus cellarius (55 or 41), Discus rotundatus (33), Oxychilus draparnaudi (31), Helix pomatia (22), and Limax maximus (21). Many of these species are typical for cellars. The most common species in caves are members of the genus Oxychilus: $O$. cellarius (26 individuals) and O. glaber (16). In galleries, Limax maximus (26 and 24 specimens), $L$. cinereoniger (14), and Helicigona lapicida (15), can occur in mass numbers there. Many of species can be found in bunkers in large numbers, e.g. Cochlicopa lubrica (135 or 70 individuals), Petasina unidentata (86), Alinda biplicata (82), Monachoides incarnatus (76) or Isognomostoma isognomostomos (60).

Some populations could survive in subterranean shelters for several generations, which explains slightly (but visibly) depigmentated populations of Arianta arbustorum in cellars No. 4 and 139 (Horní Luby and Lčovice), Cepaea nemoralis in cellar No. 9 (Skalná) or Oxychilus cellarius in gallery No. 69 (Čepice).

Some species (namely genus Oxychilus and Limax) often penetrate into deeper parts of galleries - Bečov nad Teplou No. 25, Amálino údolí No. 87 - and caves - Strašín No. 113, Malenice No. 141. Cellars under research do not have parts with higher distances from the entrances. The exact measurements came from the gallery in Čepice No. 69. So, Limax maximus was found $38 \mathrm{~m}$ deep, Arion subfuscus, $49 \mathrm{~m}$, and Oxychilus cellarius $69 \mathrm{~m}$ deep in this gallery.

The findings of big individuals of several common species also indicate, that subterranean spaces are suitable for the occurrence of gastropods. E.g., individuals of Oxychilus cellarius from cellars No. 100 (Kašperské Hory) were up to $10.9 \mathrm{~mm}$ wide, those from cave no. 55 (Chýnov) up to $11.1 \mathrm{~mm}$, and those from cellars no. 68 (Budětice) regularly more than $10 \mathrm{~mm}$, but up to $14.2 \mathrm{~mm}$ wide! Similarly wide shells had individuals of Oxychilus draparnaudi from cellars Nos. 36, 43, and 139 (Liblín, Chotěšov, Lčovice) $13.2,13.2$, and $14.6 \mathrm{~mm}$, respectively. In addition, individuals of third Oxychilus species, O. glaber, were up to $13.0 \mathrm{~mm}$ wide in cave No. 145 (Sudslavice). Other gastropods (including Helicidae) had sporadiccally big shells too.

Some species have hibernated in subterranean shelters. This feature was not studied or observed regularly, but it was conducted for big species predominantly, e.g. for Helix pomatia or Arianta arbustorum.

\section{Conclusions}

The author has found 53 species of gastropods in 160 subterranean shelters (caves, cellars, galleries, and bunkers). The cave fauna comprised typical species of surrounding biotopes with one interesting species: Oxychilus glaber. The most typical species for galleries were slugs and Helicigona lapicida. Predominantly euryoecious species were found in cellars. The most interesting one is Limacus flavus, which occurs irregularly in the Czech Republic. The gastropods fauna of the bunkers is formed by species of surrounding biotopes, including remarkable species such as Bulgarica cana or Clausilia cruciata. The author presents basic facts indicating regular using of subterranean shelters by gastropods - mass occurrence, partly depigmentated populations, occurrence in deeper parts of some localities and big shells of some species.

\section{References}

BAADE H., 2003: Die Verbreitung von Limacus flavus (Linnaeus, 1758) in Ostdeutschland (Gastropoda: Stylommatophora: Limacidae). - Malakologische Abhandlungen, 21: 91-121.

DVOřÁK L., 1999: Malakofauna sklepů, štol a jeskyní západních Čech a oblasti Šumavy [Molluscs of cellars, galleries and caves of West Bohemia and of the Bohemian Forest region]. - Silva Gabreta, 3: $141-154$.

DVOŘÁK L., 2003: Snails in the limestone caves of the Bohemian Forest foothills (SW-Bohemia). - Malacologica Bohemoslovaca, 2: 27-30.

JUŘIČKOVÁ L., 1995: Měkkýší fauna Velké Prahy a její vývoj pod vlivem urbanizace [Molluscan fauna in the territory of Prague agglomeration and its development in urban influence]. - Natura Pragensis - studie o prírodě Prahy, 12: 1-212.

JuŘIČKOVÁ L., HORSÁK M. \& BERAN L., 2001: Checklist of the molluscs (Mollusca) of the Czech Republic. - Acta Societatis Zoologicae Bohemiae, 65: 25-40.

Kerney M.P., CAMERON R.A.D. \& Jungbluth J.H., 1983: Die Landschnecken Nord- und Mitteleuropas. - Verlag Paul Parey, Hamburg und Berlin, 384 pp.

KLAUSNITZER B., 1988: Schnecken (Gastropoda), pp. 163-167. - In: Vestädterung von Tieren. A. Ziemsen Verlag, Wittenberg Lutherstadt, 315 pp.

LOŽEK V., 1956: Klíč československých měkkýšů [Key to the Czechoslovak molluscs]. - Vydavatel'stvo SAV, Bratislava, 437 pp.

Pruner L. \& MíkA P., 1996: Seznam obcí a jejich částí v České republice s čísly mapových polí pro sít'ové mapování fauny [List of settlements in the Czech republic with associated map field codes for faunistic grid mapping systém]. - Klapalekiana, 32(Suppl.): 1-175. 
RIEDEL A., 1996: Die in West-Paläarktis unterirdisch lebenden Zonitidae sensu lato (Gastropoda, Stylommatophora). - Fragmenta faunistica, 39, 24: 363-390.

SEIDL F., 1995: Die Verbreitung der Limacidae (Gastropoda, Pulmonata) im Bezirk Braunau am Inn, Oberösterreich. - Nachrichtenblatt der Ersten
Vorarlberger Malakologischen Gesellschaft, 3: $36-55$.

STRZELCZYK P., 1995: Ökofaunistische Studie zur Evertebratenfauna tiefer Gewölbekeller in der Kernstadt von Bautzen als Beitrag zur Kenntnis der Domikolfauna. - PhD. thesis, University Leipzig. 